\title{
GAGAUZI W BUŁGARII, W MOŁDAWII ORAZ NA UKRAINIE - WYBRANE ASPEKTY
}

\author{
JERZY HATŁAS
}

\begin{abstract}
The Gagauz people in Bulgaria, Moldova and Ukraine - chosen aspects.
The Gagauz people are an interesting example of a modern micro-nation. They came into being on the Balkan Peninsula. Yet their ethnogenesis is a mystery since direct written sources are missing. There are many theories about their origin. The Gagauz are most frequently perceived as a people of the Turkic origin. Bulgarian scholars view them as Turkified Bulgarians. In the very Bulgaria there remained only very few Gagauzians. This state of affairs is caused by the fact that the majority of Gagauzians emigrated and the remaining ones underwent assimilation. Nowadays they mainly inhabit Bessarabia (in southern Moldova or the western part of the Odessa district in Ukraine). In Moldova their autonomy is recognized by the state. The Gagauzian identity looks different in those three countries. In Bulgaria Gagauzians still have a double identity. They feel both Gagauzians and Bulgarians. In Moldova and Ukraine, in turn, they consider themselves as a separate nation. As far as the Gagauzian faith is concerned, they are everywhere mainly connected with the Orthodox faith. In regard to the Gagauzian-Bulgarian antagonisms one can state that these are the echo of times gone by. These days cooperation and neighborly relations prevail. In their attitudes to Russia, Bessarabian Gagauzians are predominantly Russophiles. Nostalgia for communism and the USSR is widespread. Gagauzians in Bulgaria are not anti-Russian but their view of Russia is not solely idealistic.
\end{abstract}

Autor: Jerzy Hatłas, Uniwersytet im. Adama Mickiewicza, Biblioteka Uniwersytecka, ul. Ratajczaka 38/40, 61-618 Poznań, Polska-Poland; e-mail: jurgis@amu.edu.pl

Słowa kluczowe: Gagauzi, Bułgaria, Mołdawia, Ukraina

Keywords: Gagauzians, Bulgaria, Moldova, Ukraines

Balcanica Posnaniensia. Acta et studia, XXII/2, Poznań 2015, Wydawnictwo Instytutu Historii UAM, pp. 101-116, ISBN 978-83-63047-88-7, ISSN 0239-4278. Polish text with a summary in English.

Jednym z niezwykle ciekawych współczesnych mikronarodów są z całą pewnością Gagauzi ${ }^{1}$. Ich historyczną ojczyzną jest Bułgaria. To tam właśnie doszło do

\footnotetext{
${ }^{1}$ Wybrana literatura dotycząca Gagauzów: И. Титоров, Българите в Бесарабия, Печатница на Г.А. Ножаров, София 1903, s. 279-289; А. Манов, Потеклото на гагаузите и техните обичаи и нрави, Ч. 1-2, Печатница Светлина, Варна, 1938, ss. 182; W. Zajączkowski, Przyczynki do etnografii Gagauzów, „Rocznik Orientalistyczny”, t. 20, 1956, s. 353-360; О.К. Каранастас-Радова, Гагаузы в составе задунайских переселенцев и их поселения в Буджаке (конеи XVIII - первая четверть XIX вв); Tipogr. Komratskogo Gos. Un-t, Кишинев - Комрат 2001, ss. 131; В. А. Мошков, Гагаузы Бендерского уезда (Этнографические очерки и материалы), Tipogr. Centrală, Кишинев 2004, ss. 493; A. Măcriş A., Găgăuzii din Basarabia în trecut şi în prezent, Editura Agerpress Typo, București 2003, ss. 155; Istoria Basarabiei de la începuturi până în 2003. (red. I. Scurtu), Editura Institutului Cultural Român, Ed. 3, București 2003, ss. 606; Е. Иванова, Гагаузите в Молдова, Международен Център за Изследоване на Малцинствата и Културните Взаимодействия (ИМИР), София 2004, ss. 13;
} 
skonsolidowania się tego etnosu. Etnogeneza Gagauzów stała się przedmiotem wielu dociekań naukowych oraz spekulacji. Problemem jest fakt, iż jak dotąd brak jest jakiegokolwiek źródeł pisanych związanych bezpośrednio z pochodzeniem Gagauzów. Taka sytuacja otwiera drogę do szerzenia wielu spekulacji oraz teorii, które mają oparcie wyłącznie w źródłach pośrednich. Niektóre z nich można uznać jako stojące wręcz na pograniczu „bajkopisarstwa”. Dodatkowo niemałą rolę na poparcie takiej czy innej wizji etnogenezy Gagazów ma polityka, co z przykrością należy odnotować. Taka sytuacja prowadzi do ogólnego chaosu a badacze dalecy są od wypracowania chociażby jakiejś wspólnej, w miarę zbliżonej do siebie, wizji kreacji tego etnosu.

Wynikiem mających miejsce w przeszłości kilku fal migracji z Półwyspu Bałkańskiego jest fakt, że obecnie podstawowy demograficznie trzon Gagauzów znajduje się na terytorium Besarabii, podczas gdy w Bułgarii pozostało ich już niewielu. Odnosząc to terytorium (mieszczące się miedzy rzekami Prut i Dniestr) do współczesnego podziału geograficzno-politycznego łatwo zauważyć, że większość tego etnosu zamieszkuje w południowej części Mołdawii i na Ukrainie (przede wszystkim południowo-zachodnią część odwodu odeskiego) - czyli w tak zwanym Budziaku. Znacznie mniejsze skupisko Gagauzów na Ukrainie istnieje nad Morzem Azowskim oraz na Krymie- daleko od Besarabii.

\section{PODSTAWOWE TEORIE POCHODZENIA GAGAUZÓW}

Jest wiele teorii dotyczących etnogenezy Gagauzów². Jako podstawę ich tworzenia przyjmowane są różne kryteria (historia, język, kultura materialna i duchowa itd.). W tym miejscu wymienię zaledwie kilka z nich w myśl których Gagauzi to:

Н.С. Державин, О наименовании и этнической принадлежности гагаузов [Из журнала Советская Этнография 1937 нр 1, с. 80-87], Tipogr. „Elena-V.I.”, Кишинэу 2005, ss. 24; Ф. Ангели, Гагаузская Автономия. Люди и факты (1989-2005 г2.), Universul; Кишинев 2006, ss. 260; История и культура гагаузов (coord.S. Bulgar), Pontos, Комрат - Кишинэу 2006, ss. 740; Ф. Ангели, Очерки истории гагаузов - потомков огузов (середина VIII - начало XXI вв.), Tipogr. Centrală, Кишинев 2007, ss.639; A. Măcriş, Găgăuzii, Editura PACO, Bucureşti 2008, ss. 204; М. Кендигелян, Гагаузская Республика. Борьба гагаузов за национальное самоопределене. 1989-1995. Воспоминания. Документы, Тіроgr. Centrală, Комрат 2009, ss. 605; T. Zanet, Gagauzluk: Kultura, ruh, adetlär, Pontos, Chişinău 2010, ss. 554; J. Hatłas, The Gagauz People in Bessarabia, „Słupskie Studia Historyczne” 2011 nr 17, s. 191199; Болгары и гагаузы в многонациональной Молдове: история и современность. Материалы Международной научно-практической конференции 25 февраля 2010 г. (Ред. Н.Д. Руссев), Славена, Варна 2011, ss. 105; Гагаузы (ред. М.Н. Губогло, Е.Н. Квилинкова), Наука, Москва 2011, ss. 614; Гагаузы (ред. М.Н. Губогло, Е.Н. Квилинкова), Наука, Москва 2011, ss. 614; Гагаузы в мире и мир гагаузов. (Ред. М.Н. Губогло), Tipogr. Centrală, Т. 1, Комрат - Кишинёв 2012, ss. 754; Гагаузы в мире и мир гагаузов. (Ред. М.Н. Губогло), Tipogr. Centrală, Т. 2, Комрат - Кишинёв 2012, ss. 1012.

2 В. Зайончковски, К этногенезу гагаузов, „Folia Orientalia” 1974 nr 15, s. 77-86; A. Decei, Relaţii româno-orientale. Problema colonizării turcilor selgiucizi în Dobrogea secolului al. XIII-lea. Culegere de studii, Editura Ştinţifică şi Enciclopedică, Bucureşti 1978, s. 169-192; Е. Боев, Не заблудата а лъжата за гагаузите, Изд. авт., София 1995, ss.16; Д. Гургуров, Гагаузы - потомки тюрок-огузов или славяно-болгар?, Родно слово, Кишинев 1998, ss. 162; Етногенез и этническая история гагаузов. 
1. Potomkowie Uzów, Oguzów.

2. Pochodzą od Kumanów (Połowców).

3. Potomkowie Protobułgarów.

4. Pochodzą od Turków seldżuckich (jako potomkowie wojowników towarzyszących sułtanowi Iseddinowi Kaykakusowi II, osiedlonych w Dobrudży przez Michała Paleologa).

5. Są sturczonymi Bulgarami.

6. Gagauzi to Grecy.

7. Są oni efektem zmieszania ze sobą różnych substratów turkijskich

8. Stanowią efekt zmieszania ze sobą różnych nacji (niekoniecznie turkijskiego pochodzenia).

Linia podziału w kwestii pochodzenia Gagauzów przebiega przede wszystkim na uznaniu czy Gagauzi przynależą do szeroko rozumianego świata turkijskiego czy też należy upatrywać w nich Słowian (konkretnie Bułgarów). Wobec ciągle niejasnej sytuacji etnogenezy, zdaniem autora niniejszego tekstu nadal całkowicie aktualne jest stwierdzenie cytowane przez zasłużonego polskiego orientalistę prof. Włodzimierza Zajączkowskiego, który pół wieku temu przychylił się do opinii wielu badaczy, iż „Gagauzi to lud zagadkowego pochodzenia"3. Badacze bułgarscy i bułgarskiego pochodzenia w większości popierają koncepcję w myśl której są oni sturczonymi Bułgarami a władze państwowe tego kraju (podobnie jak i spora część naukowców) traktują ich jako integralną część narodu bułgarskiego. Przywoływana jest często stara legenda mówiąca o tym jakoby władze tureckie postawiły przed podbitą ludnością bułgarską ultimatum, iż Bułgarzy muszą się wyrzec wiary chrześcijańskiej lub własnego języka i przejść na turecki ${ }^{4}$. Nie ma na to przekonywujących argumentów. Język gagauski, aczkolwiek spokrewniony z tureckim, jest jednak odrębnym bytem. Nie da się jednak zaprzeczyć, że kultura materialna oraz duchowa Gagauzów, ich folklor, nie różnią się znacząco od Bułgarów. I jedni i drudzy pod względem wyznania są w przeważającej mierze prawosławni. Długi okres czasu zamieszkiwania obu tych substratów razem (najpierw w Bułgarii a potem w Besarabii) doprowadził nieuchronnie do unifikacji kulturowej. Jedynym markerem całkowicie odróżniającym Gagauzów od Bułgarów jest zatem tylko ich własny język - gagauski - który przynależy do grona języków turkijskich. Można zgodzić się natomiast ze stwierdzeniem,

Материаль и исследования посвяшченные 150-летию В. Мошкова. Выпуск 1. [Составнение и редакция С.С. Курогло], Serv-Grafica Centrul de editură „Ekim” basım1, Кишинев - Етулия 2002, ss. 232; А. Шабашов, Гагаузы: система терминов родства и происхождение народа, Астропринт, Одесса 2002, s. 306-657; В. Матеева, Гагаузите - още един поглед, Академично Издателство „Марин Дринов”, София 2006, s. 23-36; Д. Гургуров, „Язык поменяем, но веру сохраним!” или истина о происхождени гагаузов, Tipogr. Centrală, Chişinău 2008, ss. 128; J. Hatłas, Gagauzja i Gagauzi. Historia oraz współczesność, Biblioteka Uniwersytecka w Poznaniu. Instytut Wschodni UAM, Poznań 2009 , s. 20-28.

3 В. Зайончковски, $К$ этногенезу ..., s. 77.

4 Д. Гургуров, ,,Язык поменяем, но веру сохраним!” или.... - autor ten mieszka w bułgarskiej wsi Korten na poludniu Mołdawii i jest zagorzałym zwolennikiem tej tezy. 
że Gagauzi razem z Bułgarami stanowią pewną integralną zbiorowość pod względem terytorialnym, historycznym oraz kulturowym. Natomiast kwestię etnogenezy trzeba pozostawić otwartą do momentu aż będziemy dysponowali chociaż jednym bezpośrednim źródłem pisanym dotyczącym powstania tego etnosu.

\section{DYSLOKACJA ORAZ LICZEBNOŚĆ GAGAUZÓW W BUŁGARII, W MOŁDAWII ORAZ NA UKRAINIE}

Bułgaria, a dokładniej Dobrudża, jest historyczną ojczyzną Gagauzów. To tutaj doszło do konsolidacji tego etnosu. O ile jednak pierwsze badania naukowe dotyczące historii, kultury i języka Gagauzów związane są z terytorium Bułgarii to obecnie na tym obszarze pozostała tylko niewielka ilość przedstawicieli tego narodu. Przyczynami takiego stanu były liczne migracje - zwłaszcza do Besarabii - oraz stopniowa asymilacja tych, którzy pozostali na miejscu. Według danych z roku 1926 odnotowano w Bułgarii 4362 osoby, które określały siebie jako Gagauzi ${ }^{5}$. Bezapelacyjnie największe ich skupisko, gdyż aż 3506 zamieszkiwało ówczesny okręg Warna obejmujący tereny północno-wschodniej Bułgarii ${ }^{6}$. W okręgu Burgas odnotowano już tylko 543 osoby $^{7}$. Oficjalne statystyki wskazują w ostatnich dziesięcioleciach na niewielką ilość Gagauzów zamieszkujących Bułgarię ale nieoficjalne dane pochodzące z końca lat 70. XX wieku oscylowały wokół 40.000 osób $^{8}$. Informacje z roku 1992 mówią z kolei o zaledwie ok. 1478 osobach $^{9}$. W innych częściach Bułgarii obecność Gagauzów jest tylko śladowa ${ }^{10}$.

W czasach nam obecnych niewiele miejscowości w Bułgarii jest zdominowanych etnicznie przez Gagauzów. Jedną z nich jest wieś Generał Kantardżijewo (stara gagauska nazwa to Çauş küü), którą to autor niniejszego tekstu odwiedził w dniu 20 czerwca 2011 roku (wraz z prof. Iwanam Rusewem z Uniwersytetu Ekonomicznego w Warnie). Położona jest ona w odległości ok. 30 km na północny-wschód od Warny. Wieś Generał Kantardżijewo zamieszkuje ok. 400 stałych mieszkańców. Przez okoliczną ludność bułgarską jest ona postrzegana jako bogata i świetnie prosperująca. W miejscowości tej znajduje się budynek lokalnej administracji (kmectwo), a także budynek cerkwi prawosławnej ${ }^{11}$.

${ }^{5}$ И. Градешлиев., Гагаузите, Издателска къшта „Людмил Бешков”, Добрич 1994, s. 96.

${ }^{6}$ Ibidem, s. 95.

${ }^{7}$ Ibidem, s. 94.

8 Гагаузите в България. Записки от терена (Съставител Ж. Стаменова), Исторически музей Каварна, София 2007), s. 7.

${ }^{9}$ В. Матеева, Гагаузите - още..., s. 21.

${ }^{10}$ Г. Георгиев, Д. Ангелова, Одринските гагаузи и техните потомци в Ямболско и Свиленградско. Историко-културни аспекти в развоя на традициите и идентичността им [w:] Миграции от двете страни на българо-турската граница: наследства, идентичности, интеркултурни взаимодействия. Конференция, София, 2-3 декември 2011, София 2012, s. 248-268.

${ }^{11}$ Szerzej o tym pisałem w: J. Hatłas, Gagauzi jako przykład współczesnego mikronarodu, „Poznańskie Studia Slawistyczne” nr 8 2015, s. 318-319. 
Z rozmów przeprowadzonych z kilkoma mieszkańcami wsi wynika, iż znajomość języka gagauskiego jest bardzo słaba. Włada nim już tylko najstarsze pokolenie. Tak jak w przeszłości, Gagauzi w Bułgarii, wykazują podwójną samoidentyfikację. Czują się oni Gagauzami ale także i Bułgarami. Co ciekawe, w Bułgarii miejscowi Gagauzi nazywają język swoich przodków częściej tureckim niż gagauskim.

Współczesna mapa osadnictwa gagauskiego w Bułgarii obejmuje przede wszystkim obwody Warna oraz Dobricz. W innych częściach tego państwa można odnotować tylko niewielkie grupy Gagauzów, wręcz tylko poszczególne osoby.

Gagauzi zamieszkujący w Mołdawii oraz na Ukrainie są potomkami kilku fal emigracyjnych, której apogeum miało miejsce 200 lat temu. Wtedy to władze carskie, podczas licznych wojen z Turcją, sprowadzały do południowej Besarabii (zwanej Budziakiem) osadników z ziem bułgarskich na obszary, które początkowo należały do Turcji. W roku 1812 cała Besarabia została przyłączona do Rosji i wtedy też przesiedlono (w przeważającej mierze dobrowolnie) wielu osadników z Półwyspu Bałkańskiego na ziemie skąd z kolei siłą deportowano Tatarów nogajskich.

Obecnie w granicach Mołdawii Gagauzi zamieszkują przede wszystkim na południu tego państwa. Dane dotyczące osadnictwa pod względem etnicznym są przybliżone. Z ok. 170 tys. mieszkańców Gagauzji, Gagauzi stanowią zdecydowaną większość. Pozostała część rozrzucona jest w innych częściach kraju (łącznie z Naddniestrzem nad którym władze w Kiszyniowie nie mają jurysdykcji). Na południu Mołdawii utworzono w 1994 roku autonomię. Jej oficjalna nazwa to Terytorium Autonomiczne Gagauzja (Gagauz Yeri) $^{12}$. Gagauzja posiada swoje władze oraz symbole. Najwyższym urzędnikiem jest baszkan - obecnie funkcje tę sprawuje Irina Włach.

Na dzień dzisiejszy brak jest dokładnych danych dotyczących liczebności populacji Gagauzów na Ukrainie ${ }^{13}$. Według spisów radzieckich w roku 1959 było ich 23 530, w roku 1970 - 26 464, w roku 1979 - 29398 osób a w roku 1989 - 31967. Zgodnie ze spisem powszechnym, który odbył się na Ukrainie w roku 2001 populacja Gagauzów wyniosła 31923 osoby $^{14}$. Ilość Gagauzów nie zmieniła się zatem zasadniczo od ostatniego spisu powszechnego przeprowadzonego na terytorium ZSRR w roku 1989. Liczba wszystkich Gagauzów w ZSRR według danych tego spisu wyniosła $198000^{15}$.

12 M. Kosienkowski, Geneza, status i funkcjonowanie terytorium autonomicznego Gagauzja., „Stosunki Międzynarodowe International ”. T. 36, 2007, nr 3-4, s. 205-217; Автономно-Территориальное Образование Гагаузия: Анализ экономического положения и потенциала развития (Коорд. Валериу Прохицки), Bons Offices SRL, Chişinău 2008, ss. 247; Gagauziya. Moldova Respublikasında Gagauz Avtonomiyasının 10-uncu Yildönümü (Автор текста и составител С. Булгар), Tipografia Centrală, Komrat 2006, ss. 325; Gagauziya. Moldova Respublikasında Gagauz Yeri Avtonom Bölgesi (Оформил Г. Корниенко, А. Корниенко), Proart, Kišinev-Komrat 2009, ss. 96.; Гагаузская Республика АТО Гагаузия (Gagauz Yeri). 20 лет истории 1990-2010 г (Сост. и оформ. А.Г. Корниенко, Г.И. Корниенко), ProArt, Комрат 2010, ss. 328.

13 Drugi ogólnoukrański spis powszechny ludności został odroczony i ma się on odbyć dopiero W roku 2016.

14 http://2001.ukrcensus.gov.ua/publications/ [dostęp: 25.07.2015 r.].

15 А. Шабашов, Гагаузы: система терминов родства.., s. 17. 
Gagauzi zamieszkujący na Ukrainie są drugą co do wielkości grupą tego etnosu (po Mołdawii). Najwięcej ich mieszka w poludniowej części Budziaku, jednakże nie licząc dużych miast kosmopolitycznych takich jak Kijów i zwłaszcza Odessa można ich spotkać w północnym Nadazowiu oraz na Krymie (który w roku 2014 został zaanektowany przez Rosję). I tak we wschodniej części Krymu znajduje się miejscowość Borisowka (nazwa ukraińska Борисівка, krymsko-tatarska Suin Eli - obowiązywała ona do roku 1948), której to mieszkańcy są w przeważającej części Gagauzami.

Tab. 1. Miejscowości w ukraińskiej części Budziaku zdominowanie etnicznie przez Gagauzów oraz wsie o sporej ilości ludności gagauskiej

\begin{tabular}{|c|c|c|c|}
\hline Lp. & Nazwa miejscowości & $\begin{array}{c}\text { Przynależność } \\
\text { administracyjna }\end{array}$ & $\begin{array}{l}\text { Populacja Gagauzów } \\
\text { w danej miejscowości }\end{array}$ \\
\hline 1. & $\begin{array}{l}\text { Aleksandrowka } \\
\text { (ros. Александровка, ukr. } \\
\text { Олександрівка gag. Lisandrovka, } \\
\text { nazwa historyczna - Salalık Haci }\end{array}$ & Rejon bołgradski & $\begin{array}{l}\text { Zdecydowana większość } \\
\text { z } 2341 \text { mieszkańców }\end{array}$ \\
\hline 2. & $\begin{array}{l}\text { Czerwenoarmejskoje } \\
\text { (ros. Червеноармейское, ukr. } \\
\text { Червоноармійське, gag. Kubey }{ }^{16} \text { ) }\end{array}$ & Rejon bołgradski & $33 \%$ z 6796 mieszkańców ${ }^{17}$ \\
\hline 3. & $\begin{array}{l}\text { Dmitrowka, Dimitrowka } \\
\text { (ros. Дмитровка, Димитровка; } \\
\text { ukr. Дмитрівка, gag. Dimitrovka) }\end{array}$ & Rejon bołgradski & $\begin{array}{l}\text { Zdecydowana większość } \\
\text { z } 4653 \text { mieszkańców }\end{array}$ \\
\hline 4. & $\begin{array}{l}\text { Kotłowina } \\
\text { (ros. Koтловина, ukr. Котловина, } \\
\text { gag. Bolboka) }\end{array}$ & Rejon renijski & $\begin{array}{l}\text { Zdecydowana większość } \\
\text { z } 2854 \text { mieszkańców }\end{array}$ \\
\hline 5. & $\begin{array}{l}\text { Nowosjołowka } \\
\text { (ros. Новосёловка, .ukr. } \\
\text { Новоселівка, gag.Yeni küü) }\end{array}$ & Rejon kilijski & 33\% z 1784 mieszkańców \\
\hline 6. & $\begin{array}{l}\text { Stare Trojany } \\
\text { (ros. Старые Tраяны, ukr. Старі } \\
\text { Tрояни, gag. Eski Troyan / Yeski } \\
\text { Troyan) }{ }^{18}\end{array}$ & Rejon kilijski & 69\% z 2583 mieszkańców \\
\hline 7. & $\begin{array}{l}\text { Winogradowka }{ }^{19} \\
\text { (ros. Виноградовка, ukr. } \\
\text { Виноградівка, gag. Kurçu / } \\
\text { Kurçi) }\end{array}$ & Rejon bołgradski & 71\% z 4057 mieszkańców \\
\hline
\end{tabular}

${ }^{16}$ Кубей и кубейци. Бит и култура на българите и гагаузите в с. Червеноармейское, Болградски район (А. Пригарин еt alii), Одеска област, Маяк, Одеса 2002, ss. 86.

17 Sytuacja etniczna w tej miejscowości jest mocno skomplikowana, gdyż dane z różnych przedziałów chronologicznych wykazywały raz przewagę Gagauzów a innym razem Bułgarów.

18 Autor niniejszego tekstu (wraz ze znajomymi krajoznawcami z mołdawskiej Tarakliji) odwiedził Stare Trojany w dniu 14 listopada 2015 roku. Dojazd do tej miejscowości jest fatalny. Sporą część drogi samochód osobowy pokonywał polną drogą lub wręcz polami, gdyż asfaltowa droga prowadząca od strony bułgarskiej wsi Kirniczki jest w tak fatalnym stanie, iż nie nadaje się do użytku.

19 С. Булгар, Виноградовка (Курчи). История села (1811-2011 г2.), ВМВ, Одесса 2011, ss. 434. 


\section{SAMOIDENTYFIKACJA GAGAUZÓW W BUŁGARII, W MOŁDAWII ORAZ NA UKRAINIE}

Autor niniejszego tekstu wielokrotnie odwiedził Gagauzję, która znajduje się na południu Mołdawii, gdzie prowadził badania bibliograficzne oraz terenowe (miałem okazję zobaczyć wszystkie miejscowości należące do autonomii gagauskiej). Przebywałem także w sześciu z siedmiu miejscowościach ukraińskiego Budziaku (Aleksandrowka, Czerwenoarmejskoje, Dmitrowka, Kotłowina, Stare Trojany oraz Winogradowka) zamieszkałych przez Gagauzów a w Bułgarii odwiedziłem zdominowaną przez Gagauzów wieś Generał Kantardżijewo. Z przeprowadzonych rozmów z mieszkańcami poszczególnych miejscowości w tych trzech państwach wyłania się obraz poszczególnych zbiorowości, który jak się okazało nie jest monolitem. O ile w Bułgarii nadal istnieje stara historyczna podwójna samoidentyfikacja Gagauzów, którzy mówią o sobie, „iż jesteśmy Gagauzami ale także i Bułgarami” to w Besarabii nastąpiła już pełna atomizacja. Gagauzi w Mołdawii oraz na Ukrainie czują się odrębnym narodem a z Bułgarami co najwyżej dostrzegają stare więzy historyczne. Odseparowanie Gaguzów od Bułgarów przebiegało dwuetapowo. W Besarabii najpierw dokonali tego odgórnie Rumuni w okresie międzywojennym, kiedy to w oficjalnych spisach powszechnych ludności Gagauzi pojawili się jako odrębna narodowość. Rumunom zależało na zatrzymaniu w swoich granicach możliwie całej Dobrudży zamieszkanej w dużym stopniu przez Bułgarów. Zabieg techniczny z wypromowaniem Gagauzów miał udowodnić, iż w Dobrudży społeczność bułgarska jest dużo mniejsza niż twierdziły to władze w Sofii, ponieważ znaczną jej część stanowi populacja, która jest pochodzenia turkijskiego. W czasach przynależności Besarabii do ZSRR władze radzieckie także czyniły zabiegi związane z emancypacją Gagauzów. Dotyczyło to jednak tylko obszaru południa Mołdawii, gdyż na Ukrainie tego typu eksperymentów nie podejmowano. Na obszarach zdominowanych przez ludność gagauską na południu Mołdawskiej SRR wprowadzono nawet przez krótki okres czasu nauczanie w szkole w języku gagauskim. Eksperyment ten nie udał się, nie bez udziału winy samych Gagauzów, którzy nie chcieli aby ich dzieci kształciły się w swoim języku (który należy do grupy języków niszowych), gdyż zadaniem rodziców stawiał on ich dzieci w gorszej sytuacji w ewentualnej dalszej karierze.

Drugi etap emancypacji Gagauzów wyszedł już z własnego środowiska. Burzliwa końcówka lat osiemdziesiątych XX wieku (gorbaczowowska pierestrojka a dalej upadek ZSRR) stały się zarzewiem ruchu narodowego. Od tego czasu sami Gagauzi świadomie zaczęli się identyfikować jako samodzielny niezależny byt odseparowany od narodu bułgarskiego. 


\section{PRZYNALEŻNOŚĆ RELIGIJNA GAGAUZÓW}

Gagauzi, aczkolwiek używają własnego języka gagauskiego, który należy grona języków turkijskich, historycznie związani są z prawosławiem. Tak było w Bułgarii jeszcze przed przesiedleniem na Wschód, jak i później.

W Bułgarii na obszarach zamieszkałych przez Gagauzów bezapelacyjnie dominuje prawosławie. We wsi Generał Kantardżijewo istnieje zadbany budynek cerkwi prawosławnej ${ }^{20}$. W czasach komunizmu walczono $\mathrm{z}$ wszelkimi religiami, co doprowadziło w znacznym stopniu do przymusowej ateizacji społeczeństwa. $Z$ drugiej jednak strony, wiele starych zabytkowych prawosławnych obiektów sakralnych zostało uznanych jako pomniki kultury. Dzięki takiemu zabiegowi nie niszczono ich (w przeciwieństwie do meczetów, których ilość w latach 1955-1989 została zredukowana) a sporo z nich (cerkwie oraz klasztory) pełniło jednocześnie funkcje sakralne oraz turystyczne.

Dużo gorzej kwestie wolności religijnych wyglądały na obszarach przyłączonych do ZSRR. W Besarabii zamykano masowo cerkwie a kler represjonowano. Budynki świątyń zmieniały swoje przeznaczenie. Urządzano w nich muzea, magazyny, sale gimnastyczne itd. Wiele z nich było pustostanami a niemało zwyczajnie zniszczono. W tym ostatnim przypadku zburzenie cerkwi motywowano najczęściej poprowadzeniem akurat w tym miejscu nowej drogi, budową nowej szkoły lub domu kultury. Na obszarze obecnego Terytorium Autonomicznego Gagauzja (Gagauz Yeri) w czasach istnienia ZSRR były czynne zaledwie dwie cerkwie (w miejscowościach Kongaz oraz Czok Majdan). Zdecydowanie gorzej sytuacja wyglądała na obszarach, które najpierw znajdowały się w granicach Rosji, potem Rosji Radzieckiej i ZSRR, czyli Krym oraz północne Nadazowie. Tam obraz destrukcji obiektów sakralnych został zrealizowany niemalże w całości. Po wielu cerkwiach nie pozostały nawet fundamenty. Specyfiką Besarabii natomiast jest pewien pluralizm religijny. Rozpoczął się on już w początkach XX wieku, kiedy to na ten obszar zaczęli przybywać przedstawiciele różnego rodzaju odłamów protestantyzmu. W czasach radzieckich ich działalność nie była widoczna ale o ich istnieniu można przeczytać w literaturze naukowej ${ }^{21}$. Po upadku ZSRR nastąpiła wręcz eksplozja protestantyzmu w Besarabii. Prawie w każdej miejscowości przynależącej do Gagauz Yeri istnieje minimum jeden dom modlitewny innego wyznania chrześcijańskiego. Lokalna społeczność uległa podziałowi. W Gagauzji wyremontowano i otwarto dla wiernych wszystkie zachowane budynki cerkiewne. Zbudowano także nowe obiekty w miejscowościach, gdzie świątynie zostały w czasach komunizmu zburzone lub też nigdy nie było ich tam. W obecnych czasach następuje w Besarabii renesans wiary. Niemała część społeczeństwa czuje się związana bądź z prawosławiem, bądź też z którymś z odłamów protestantyzmu. Pomiędzy różnymi odłamami chrześcijaństwa nie widać wrogości, za to Gagauzi nie

20 В. Е. Бойков, Православные храмы Гагаузии, Tipogr. Centrală, Комрат 2011, ss. 107.

${ }^{21}$ Е. Квилинкова, Религиозность гагаузов и формы проявления религиозной идентичности (по этнографическим и архивным материалам ХИХ-первой половины XX в.). [w:] Этнографические исследования в Республике Молдова (История и современность), Кишинев 2006, s. 341-363. 
wyrażają sympatii wobec islamu. Swego czasu Turcja zabiegała o zbudowanie w stolicy Gagauzji Komracie meczetu. Idea ta spotkała się jednak z otwartą wrogością ze strony mieszkańców i w końcu została ona porzucona. Obecnie w Komracie trwają prace nad zbudowaniem nowego ogromnego soboru prawosławnego przy drodze prowadzącej w kierunku miasta Czadyr Lunga (na razie w miejscu tym istnieje tylko prowizoryczna konstrukcja cerkwi) a przy nowym cmentarzu dobiega końca budowa nowej cerkwi. Trwają także zabiegi administracyjne, aby Gagauzja posiadała swoją odrębną diecezję, gdyż na dzień dzisiejszy związana jest ona z miastem Kaguł. W odniesieniu do innych wyznań, prawosławni mieszkańcy Gagauzji lubią operować terminem „sekta”, który jest po pierwsze nadużywany a po drugie niepoprawnie stosowany. Pod pojęciem, „sekta” widzi się bowiem nie tylko przedstawicieli różnych współczesnych sekt ale także każde inne wyznanie niż prawosławne ${ }^{22}$. Specyficzną cechą Besarabii jest także fakt, iż nierzadko przynależność wyznaniowa łączona jest mechanicznie z przynależnością etniczną. Niejednokrotnie bywa, iż osoba zapytana o swoją wiarę odpowiada bez zastanowienia - ,jestem prawosławny / prawosławna”. Jednakże bywa niekiedy tak, że po zadanym nieco później kolejnym pytaniu: „czy jest pan / pani wierzący / wierząca - pada odpowiedź negatywna. Można zatem przypuszczać, że w takich przypadkach działa mechanizm związany ze świadomością historyczną: skoro moi pradziadkowie, dziadkowie i rodzice byli prawosławni to ja oczywiście też jestem prawosławny / prawosławna. Jednakże takie deklaracje wiary rozmywają się niejednokrotnie całkowicie z rzeczywistością 23 .

\section{SYMPATIE I ANTYPATIE ETNICZNE ORAZ POLITYCZNE}

Istnieje spore zróżnicowanie pomiędzy zorientowaniem politycznym Gagauzów w Bułgarii a Gagauzów w Mołdawii oraz na Ukrainie. Gagauzi w Bułgarii nie są nastawieni antyrosyjsko. Rosja wyzwoliła Bułgarię z niewoli tureckiej i o tych wydarzeniach pamięta się do dzisiaj. W czasach komunistycznych w szkole przypominano dzieciom i młodzieży o tym fakcie na każdym kroku i przy każdej okazji. Można mówić zatem nawet o pewnej sympatii Gagauzów w Bułgarii do Rosji i Rosjan, ale owa sympatia nie jest bezgraniczna $\mathrm{i}$ bezkrytyczna.

Zupełnie inaczej sytuacja wygląda w Besarabii. Tutaj długotrwała indoktrynacja społeczeństwa oraz wpajanie ludziom, że tylko Rosja (lub ZSRR) oraz Rosjanie są prawdziwymi przyjaciółmi stworzyła nową sytuację. W opozycji Rumunia zawsze

22 Bliżej na ten temat w: Г. Георгиев, Е. Хатлас., Вяра,всекидневие и локална култура. Функции на религията у българите и гагаузите от Бесарабия през постсочиалистическия период. [w:] Бесарабските българи: история, култура и език (25-годишина нагрупата «Етнология на българите» в Центъра по етнология на Иститута културно наследство, АНМ и 20-годишнина на Научното дружество на българистите в Република Молдова), Кишинев«〈S.Ş.B.», 2014, s. 249-262.

${ }^{23}$ Mechanizm ten dotyczy nie tylko besarabskich Gagauzów ale także miejscowych Bułgarów. Prawdopodobnie nieobcy jest on także przedstawicielom innych narodowości zamieszkujących na tym terenie ale autor niniejszego tekstu prowadził badania tylko tych dwóch grup etnicznych. 
była oceniana bardzo negatywnie, wręcz ukazywana jako „wcielenie wszelkiego zła”. Nowa historiografia na tym terenie w sporej części bezmyślnie powtarza to samo co stworzyła propaganda i historiografia radziecka. Rosja gra na uczuciach społecznych a Unia Europejska proponując Mołdawii integrację ze strukturami europejskimi poczyniła szereg błędów ${ }^{24}$. Spora ilość ludności Gagauzji pracuje w Rosji. Także cerkiew prawosławna uznaje zwierzchnictwo rosyjskiej cerkwi prawosławnej. Rosja sponsoruje wiele inicjatyw w Gagauzji, przysyła na ten obszar z wizytami (oficjalnymi i nieoficjalnymi) swoich polityków, samorządowców, artystów, ludzi kultury, duchownych itd., którzy starają się przedstawiać każdą sprawę w optyce rosyjskiej. Zacieśniana jest współpraca gospodarcza z różnymi podmiotami gospodarczymi oraz jednostkami terytorialnymi Federacji Rosyjskiej. Tego rodzaju zabiegi Rosji nie pozostają bez echa. Przejawem radykalizujących się nastrojów prorosyjskich było referendum gagauskie przeprowadzone w początkach 2014 roku. Dotyczyło ono ewentualnego przystąpienia Gagauzji do związku celnego Rosji, Białorusi i Kazachstanu lub też integracji ze strukturami Unii Europejskiej oraz potwierdzenia woli narodu, iż w przypadku utraty niepodległości Mołdawii (na wypadek jej ewentualnego połączenia z Rumunią) Gagauzja ogłosi niepodległość. Referendum to zostało zignorowanie i uznane za niekonstytucyjne przez władze kiszyniowskie, gdyż Gagauz Yeri nie jest niepodległym państwem a więc nie może podejmować decyzji dotyczących polityki zagranicznej. Znamienny jest jednak fakt, iż 97\% mieszkańców opowiedziało się za silnym zacieśnieniem związków z Rosją a przeciwko Unii Europejskiej. Nie brak jest opinii, iż owo referendum było sponsorowane przez Rosję (zarówno finansowo jak i propagandowo).

Gagauzi w Besarabii w swoich opiniach są często bezkrytyczni w stosunku do Rosji jako państwa, wręcz zaślepieni (co z przykrością podkreślam od lat). Panuje powszechna nostalgia za czasami radzieckimi. Na każdym kroku podkreśla się zasługi Rosji oraz ZSRR. Pozytywnym aspektem jest fakt, że w ostatnich latach mówi się i pisze otwarcie o represjach oraz potwornym głodzie z lat 1946-1947, w którym to według różnych szacunków zmarło w poszczególnych miejscowościach zamieszkałych przez Gagauzów od 20 do 60\% mieszkańców. Wiedza o tych tragicznych wydarzeniach nie jest już więc skrywana. Powstały publikacje a także są budowane pomniki tych tragicznych wydarzeń - dla przykładu w Komracie, Czadyr Lundze, Beszalnie czy Awdarmie w Mołdawii oraz Kotłowinie oraz Winogradowce na Ukrainie ${ }^{25}$. Re-

${ }^{24}$ W rozmowach prowadzonych z mieszkańcami na południu Mołdawii - zarówno z Gagauzami jak i z Bułgarami - przejawia się żal, iż Unia Europejska przekazując duże pieniądze na integrację nie kontroluje ich prawidłowego wydatkowania. W obliczu ogromnej korupcji panującej w Mołdawii - zdaniem respondentów - rządzący, którzy popierają kurs proeuropejki sami rozkradają pieniądze (zarówno unijne jak i środki rodzime) podobnie jak wcześniej czynili to komuniści. Wobec tego wielu miejscowych Gagauzów oraz Bułgarów pomimo, że od zawsze byli oni nastawieni prorosyjsko, nie było jeszcze do niedawna przeciwnych integracji z Zachodem. Obecnie sytuacja ta zmieniła się diametralnie. Najczęściej wyrażane opinie z roku 2015 to stwierdzenia, iż „Nie chcemy żadnej Unii Europejskiej bo oni też nas oszukali. Możemy liczyć tylko i wyłącznie na Rosję".

25 Голод в Молдове (1946-1947). Сборник документов (Сост. А.М. Царан et alii), Штиинца, Кишинев 1993, ss. 767; Голодомори в Украйні: Одеська область 1921-1923, 1932-1933, 1946-1947. Дослідження, спогади, документи (Ред. I.I. Ніточко et alii), Державний архиів Одеської області, 
presji okresu stalinowskiego oraz potwornego głodu z lat 1946-1947 miejscowe społeczeństwo zazwyczaj nie łączy w ogóle $\mathrm{z}$ władzą radziecką i totalitaryzmem zrzucając często winę na kaprys natury (tradycyjnie za to oczernia się na każdym kroku Rumunię). Bywa i tak, że osoby zaawansowanie wiekiem, które przeżyły głód z lat 1946-1947) jeszcze w czasach obecnych boją się o tym mówić i zasłaniają utratą pamięci jak to uczyniła w rozmowie ze mną pewna kobieta ze wsi Winogradowka (Kurçu) ${ }^{26}$. $\mathrm{Z}$ taką postawą miejscowych Gagauzów wiąże się bezgraniczne zaufanie do Rosji i bycie de facto narzędziem jej polityki wobec władz centralnych Mołdawii oraz Ukrainy.

Każdy lokalny polityk w Gagauzji ubiegający się o bardziej znaczący urząd stara się już na wstępie swojej kampanii wyborczej pojechać do Rosji, aby z namaszczeniem Kremla, lub patriarchy moskiewskiego i całej Rusi Cyryla, startować w wyborach, gdyż to gwarantuje dużą liczbę głosów. Nie inaczej było też w czasie ostatnich wyborów baszkana Gagauzji w roku 2015. Wygrała je Irina Włach (Vlah), kandydatka w 100\% popierana przez Moskwę. Zarzucano jej, że głosy na siebie kupiła za pieniądze rosyjskie a także, iż korupcja oraz stopień nieprawidłowości podczas ostatnich wyborów nie posiada analogii w historii Mołdawii.

Wpływ rosyjskiej optyki i polityki w Besarabii na to co dzieje się obecnie na Ukrainie i w Mołdawii jest ogromny. Przykładem może służyć ocena wydarzeń na Ukrainie od czasów tragicznych wydarzeń na kijowskim Majdanie. Do dnia dzisiejszego są one postrzegane nie tylko przez zwykłych obywateli ale także i przez wielu badaczy gagauskich całkowicie w kategoriach propagandy moskiewskiej. Przykładem może służyć krótki wywiad z Ałłą Papcową (pracownikiem naukowym Państwowego Uniwersytetu Komrackiego w Komracie) zamieszczonym na bułgarskim portalu internetowym „news.bg”. Badaczka ta wypowiada się o obecnych władzach Ukrainy używając wyłącznie terminologii takiej jak „nacjonaliści” oraz „,banderowcy”. Teoretycznie jej wypowiedź wiąże się z Bułgarami w Besarabii, praktycznie jednak dotyczy ona w równej mierze także i Gagauzów. Zburzenie wielu pomników związanych z symbolami totalitaryzmu na Ukrainie (popularnie tak zwany „leninopad”) A. Papcowa uważa za absurdalne. $Z$ nieukrywaną dumą stwierdza, iż mieszkańcy jej rodzinnego miasta (Czadyr Lungi) w odpowiedzi na te wydarzenia specjalnie odrestaurowali swój pomnik Lenina ${ }^{27}$. W czasie ostrego konfliktu w Donbasie pojawiły się informacje, iż Gagauzi oraz Bułgarzy z Ukrainy nie chcą walczyć na froncie tej wojnie. Trudno jednak jest łączyć jednoznacznie niniejszą postawę z taką czy inną

Одеса 2007.ss. 457; К. Курдогло, Репрессии и массовые депортаци жителей с. Баурчи ЧадырЛунгского р-на Реапублики Молдова в 1940-1951 гг, Tipogr. Centrală, Баурчи-Кишинэу 2009, ss. 607; Курдогло К., Голод в Гагаузии (1946-1947 г2.), Tipografia Centrală, Комрат-Кишинев 2010, ss. 586.

26 J. Hatłas, Gagauzi jako przykład, s. 321.

27 А. Папцова, Българите в Бесарабия не са готови да умират за идеите на украинските националисти - http://news.ibox.bg/interview/id_1793546393 [dostęp: 23.05 .2015 r.]. Restaurację pomnika Lenina w mieście Czadyr Lunga przeprowadzono w roku 2014 z inicjatywy komunistów za pieniądze uzyskane od sponsorów. Pomnik ten znajduje się na miejscu zburzonej cerkwi. Po uzyskaniu przez Mołdawię niepodległości pojawiały się inicjatywy odbudowy świątyni ale ostatecznie „zwyciężył" Lenin. 
opcją polityczną władz w Kijowie. Można raczej przypuszczać, że wielu młodych ludzi nie chce umierać i to jest główny powód ich niechęci do wyjazdu na front, tym bardziej, że rosyjskie media (z których korzystają oni na co dzień) kreują w sposób niezwykle agresywny wyłącznie moskiewską wersję konfliktu na Ukrainie. Gagauzi w Mołdawii oglądają na co dzień telewizję rosyjską i tylko z niej posiadają informcje. Znajomość języka państwowego jakim jest język rumuński (nazywany tam „mołdawskim") jest bardzo słaba natomiast rosyjskiego doskonała.

\section{ZAKOŃCZENIE}

Reasumując można stwierdzić, że Bułgaria, Mołdawia oraz Ukraina to państwa silnie związane z obecnością Gagauzów i ich historią. Bułgaria jest dla nich starą ojczyzną gdzie ten etnos się uformował i skąd w przeważającej swej części wyemigrował do Besarabii oraz na inne obszary. Republika Mołdawii stanowi dla Gagazuzów obecną ojczyznę, gdzie mieszka zasadniczy trzon tego etnosu i gdzie posiada on swoje struktury protopaństwowe w formie autonomii (Terytorium Autonomiczne Gagauzja Gagauz Yeri). Na Ukrainie z kolei znajduje się druga pod względem wielkości społeczność gagauska. Nie należy jednak zapominać, że Gagauzi w Besarabii zostali przedzieleni w czasach stalinowskich sztuczną granicą, która jedne miejscowości pozostawiła w granicach Mołdawskiej SRR a inne w Ukraińskiej SRR. Tak naprawdę Gagauzi (podobnie jak i Bułgarzy) w Budziaku stanowią historycznie jedną całość, która wbrew ich woli została sztucznie rozdzielona na dwie części. O ile w czasach istnienia ZSRR owa granica była tylko czysto administracyjna to obecnie jest to granica państwowa, której przekraczanie wiąże się z wieloma uciążliwościami.

Do czasów obecnych Gagauzi pod względem wyznanej wiary nadal są kojarzeni $\mathrm{z}$ prawosławiem, ale w przeciwieństwie do Bułgarii, w Mołdawii i na Ukrainie, jest obecnie spory odsetek protestantów ${ }^{28}$. Spuścizną czasów komunistycznych jest niemała grupa ludzi niewierzących.

Pod względem sympatii i antypatii etnicznych Gagazów narosło wiele mitów, zwłaszcza jeśli dotyczy to ich relacji wzajemnych z Bułgarami. Istotnie, początkowo oba te etnosy mieszkały raczej obok siebie a nie wspólnie. Zdarzały się liczne konflikty, których reminiscencji niektórzy badacze dopatrują się jeszcze dzisiaj ${ }^{29}$. Jednakże są to fakty z zamierzchłej przeszłości. Mieszane małżeństwa, które zaczęły się na dużą skalę w Besarabii ok. pięćdziesiąt lat temu zmieniły sytuację diametralnie. Kiedy Gagauzi

${ }^{28}$ Е. Квилонкова, Православие - стержень гагаузской этничности, Tipografia Centrală, Комрат-София 2013, ss. 866.

${ }^{29}$ J. Derlicki, Zmierzch konfliktu czy jego ukryte trwanie? Bułgarsko-gagauska wieś Kirsowo, w: Między etnicznościa a lokalnościa. Pogranicze bułgarsko-gagauskie w Besarabii (red. J. Derlicki), Warszawa 2012, s. 53-65; M. Kłos, O szorstkiej przyjaźni dwóch narodów. Analiza relacji bułgarsko-gagauskich w Budziaku, w: Batkany na Ukrainie. Butgarzy, Gagauzi i Albańczycy z ukraińskiego Budziaku (red. W. Lipiński), Warszawa 2014, s. 153-166. 
walczyli o swoją suwerenność pod koniec istnienia ZSRR, Bułgarzy dali wiele dowodów zrozumienia i bezinteresownej pomocy. Bywały przypadki, że ludność bułgarska kładła się na drogach, aby uniemożliwić interwencję skierowaną przeciwko Gagauzom. Mieszkańcy zdominowanego przez Bułgarów miasta Twardica na południu Mołdawii z kolei od dawna postulują przyłączenie się do Gagauzji. Odnotować można za to powszechne wśród Gagauzów Besarabii uwielbienie dla Rosji i Rosjan. Rosyjskie władze oraz media nie ustają w swoich działaniach aby wygrywać Gagauzów przeciwko integracji zarówno Mołdawii jak i Ukrainy ze strukturami Unii Europejskiej. Pomnik Włodzimierza Lenina w Komracie, przy głównej ulicy (także imienia Lenina), nadal znajduje się przed budynkiem władz autonomii. Z kolei niekwestionowany bohater gagauski (oświeciciel, tłumacz, duchowny i działacz narodowy w jednej osobie) Michaił Czakir doczekał się jedynie skromnej tablicy pamiątkowej w Alei Chwały (Sławy), która mieści się przed głównym korpusem miejscowego uniwersytetu ${ }^{30}$. Nazewnictwo ulic na obszarze Gagauz Yeri zostało zachowane w 100\% z czasów radzieckich a pomniki wodza rewolucji, oraz sławiące Armię Czerwoną, znajdują się w wielu innych miejscowościach. W Starych Trojanach na Ukrainie pomnik Lenina stoi nadal i ma się dobrze. Składane są pod nim nadal wiązanki kwiatów.

W Bułgarii oraz na innych obszarach niż Besarabia Gagauzi czują się nadal w równym stopniu także i Bułgarami. Tylko w Besarabii nastąpiła atomizacja obu tych komponentów. Tamtejsi Gagauzi uważają się nie tylko za odrębny lud ale za całkowicie odrębny naród od Bułgarów. Skoro jednak jest to ich własny i przemyślany wybór, należy to uszanować.

Należy odnotować, że Gagauzi posiadają swój bogaty folklor i obrzędowość kalendarzową ${ }^{31}$. Istnieją zespoły artystyczne, które pieczołowicie kultywują stare pieśni i tańce. Odbywają się z ich udziałem w Gagauzji różnego rodzaju imprezy masowe jak chociażby coroczny początek lata „Hederlez” czy też Festiwal Wina w Komracie, który ostatnio odbył się 8 listopada 2015 roku i był połączony z tradycyjnym świętem gagauskim „Kasım” (początek zimy - gagauski ludowy kalendarz obrzędowy nie zna wiosny ani jesieni) $)^{32}$.

30 Протоиерей М. Чакир, История гагаузов Бессарабии. [w:] Страницы истории илитературы гагаузов XIX-нач. XX вв, Pontos, Кишинэу 2005, с. 80-108; О. Мошин, В. Копущу, Протойерей Михаил Чакир: служние Богу и ближним. К 75-летию ко дня кончины протореиея Михаила Чакира, Cuvintul ABC, Кишинев 2013, ss. 86. Michaił Czakir spoczywa na cmentarzu w Kiszyniowe mieszczącym się przy ulicy Ormiańskiej. Jest to skromna mogiła na której w roku 2011 ustawiono uroczyście brązowe popiersie. W nocy z 14 na 15 sierpnia 2015 roku nieznane osoby dokonały aktu wandalizmu. Popiersie ostało skradzione.

31 Е.Н. Квилонкова, Гагаузский народный календарь, , Pontos, Chişinău 2002, ss. 182; Е.Н. Квилонкова, Региональнье особенности традиционной духовной культуры гагаузов, На правах рукописи, Кишинев 2008; Е.Н. Квилонкова, Заговоры, магия и обереги в народной медицине гагаузов, Elan INC, Кишинев 2010, ss. 389; Е.Н. Квилонкова, Гагаузский песенный фольклор - „граматика жизни”, Elan INC, Кишинев 2011, ss. 568; Е.Н. Квилонкова, Апокрифы в зеркале народной культурь гагаузов, Tipografia Cedntrală, Кишинев-Благоевград 2012, ss. 599.

$32 \mathrm{~W}$ imprezie tej uczestniczyłem, gdyż jej termin zbiegł się z moimi ostatnimi badaniami bibliograficznymi prowadzonymi w Mołdawii. 
Kończąc można postawić pytanie w jakiej kondycji znajduje się obecnie etnos gagauski i jakie czekają go perspektywy w przyszłości? Moim zdaniem Gagauzi w Bułgarii w Mołdawii i na Ukrainie nie stanowią już monolitu. Pod względem mentalnym Gagauzi w Bułgarii są zdecydowanie bardziej prozachodni i proeuropejscy. Z kolei rozdzielenie Gagauzów w Besarabii prowadzi do kolejnego podziału na dwie odizolowane od siebie grupy, które oddalają się od siebie. Najwyższy status Gagauzi zagwarantowali sobie w Mołdawii, gdzie posiadają oficjalnie uznaną przez państwo autonomię. Problemem jest jednak fakt, że Mołdawia jest krajem biednym. Młodzi Gagauzi emigrują masowo przede wszystkim do Rosji (w mniejszym zakresie do Turcji), gdzie znajdują pracę i gdzie są ulokowane ich sentymenty. W Rosji nie ma mowy aby kiedykolwiek stworzyli dla siebie jakąkolwiek autonomię. Grozi im tam więc szybka asymilacja i rozpłynięcie się w społeczeństwie rosyjskim. Także i w Bułgarii proces asymilacji jest mocno zawansowany. We wsi Generał Kantardżijewo - o czym już wspomniano - tylko najstarsi mieszkańcy pamiętają jeszcze język przodków. Zatem perspektywy na przyszłość nie są zbyt optymistyczne ${ }^{33}$.

\section{BIBLIOGRAFIA}

Decei A., Relaţii româno-orientale. Culegere de studii, Editura Ştinţifică şi Enciclopedică, Bucureşti 1978 , ss. $245^{34}$.

Derlicki J., Zmierzch konfliktu czy jego ukryte trwanie? Butgarsko-gagauska wieś Kirsowo, [w:] Między etnicznością a lokalnościq̨. Pogranicze bułgarsko-gagauskie w Besarabii (red. J. Derlicki), Warszawa 2012, s. 53-65.

Gagauziya. Moldova Respublikasında Gagauz Avtonomiyasının 10-uncu Yildönüтӥ (Автор текста и составител С. Булгар), Tipografia Centrală, Komrat 2006, ss. 325.

Hatłas J., The Gagauz People in Bessarabia, „Słupskie Studia Historyczne” 2011 nr 17, s. 191-199.

Istoria Basarabiei de la începuturi până în 2003. (red. I. Scurtu), Editura Institutului Cultural Român, Ed. 3, Bucureşti 2003, ss. 606.

Hatłas J., Gagauzja i Gagauzi. Historia oraz wspótczesność, Biblioteka Uniwersytecka w Poznaniu. Instytut Wschodni UAM, Poznań 2009, ss. 214.

Hatłas J., Gagauzi jako przykład współczesnego mikronarodu, „Poznańskie Studia Slawistyczne” nr 8 2015, s. 318-319.

Kłos M., O szorstkiej przyjaźni dwóch narodów. Analiza relacji bułgarsko-gagauskich w Budziaku, [w:] Batkany na Ukrainie. Bułgarzy, Gagauzi i Albańczycy z ukraińskiego Budziaku (red. W. Lipiński), Warszawa 2014, s. 153-166.

Kosienkowski M., Geneza, status i funkcjonowanie terytorium autonomicznego Gagauzja., „Stosunki Międzynarodowe International ". T. 36, 2007, nr 3-4, s. 205-217.

Măcriş A., Găgăuzii din Basarabia în trecut şi în prezent, Editura Agerpress Typo, Bucureşti 2003, ss. 155 .

Măcriş A., Găgăuzii, Editura PACO, Bucureşti 2008, ss. 204.

${ }^{33}$ Niniejszy artykuł został napisany w oparciu o tezy wygłoszone podczas VII Ogólnopolskiej Konferencji Turkologicznej w Poznaniu w dniu 01.06.2015 r.

${ }^{34} \mathrm{~W}$ niniejszym tekście przy opisie bibliograficznym poszczególnych publikacji podano wszędzie tzw. strony liczbowane (czyli numerowane). 
Zajączkowski W., Przyczynki do etnografii Gagauzów, „Rocznik Orientalistyczny”, t. 20, 1956, s. 353360.

Zanet T., Gagauzluk: Kultura, ruh, adetlär, Pontos, Chişinău 2010, ss. 554.

Автономно-Территориальное Образование Гагаузия: Анализ экономического положения и потенциала развития (Коорд. Валериу Прохицки), Bons Offices SRL, Chişinău 2008, ss. 247.

Ангели Ф., Гагаузская Автономия. Люди и факты (1989-2005 гг.), Universul; Кишинев 2006, ss. 260 .

Ангели Ф., Очерки истории гагаузов - потомков огузов (середина VIII - начало XXI вв.), Tipogr. Centrală, Кишинев 2007, ss.639.

Боев Е., Не заблудата а лъжата за гагаузите, Изд. авт., София 1995, ss.16.

Болгары и гагаузы в многонаииональной Молдове: история и современность. Материалы Международной научно-практической конференции 25 февраля 2010 г. (Ред. Н.Д. Руссев), Славена, Варна 2011, ss. 105.

Бойков В. Е., Православные храмы Гагаузии, Tipogr. Centrală, Комрат 2011, ss. 107.

Булгар С., Виноградовка (Курчи). История села (1811-2011 г2.), ВМВ, Одесса 2011, ss. 434.

Гагаузите в България. Записки от терена (Съставител Ж. Стаменова), Исторически музей - Каварна, София 2007), ss. 287.

Gagauziya. Moldova Respublikasında Gagauz Yeri Avtonom Bölgesi (Оформил Г. Корниенко, А. Корниенко), Proart, Kišinev-Komrat 2009, ss. 96.

Гагаузская Республика АТО Гагаузия (Gagauz Yeri). 20 лет истории 1990-2010 г (Сост. и оформ. А.Г. Корниенко, Г.И. Корниенко), ProArt, Комрат 2010, ss. 328.

Гагаузы (ред. М.Н. Губогло, Е.Н. Квилинкова), Наука, Москва 2011, ss. 614.

Гагаузы в мире и мир гагаузов. (Ред. М.Н. Губогло), Tipogr. Centrală, Т. 1, Комрат - Кишинёв 2012, ss. 754.

Гагаузы в мире и мир гагаузов. (Ред. М.Н. Губогло), Tipogr. Centrală, Т. 2, Комрат - Кишинёв 2012, ss. 1012.

Георгиев Г., Ангелова Д., Одринските гагаузи и техните потомци в Ямболско и Свиленградско. Историко-културни аспекти в развоя на традициите и идентичността им [w:] Миграции от двете страни на българо-турската граница: наследства, идентичности, интеркултурни взаимодействия. Конференция, София, 2-3 декември 2011, София 2012, s. 248-268.

Георгиев Г., Хатлас Е., Вяра,всекидневие и локална култура. Функиии на религията у българите и гагаузите от Бесарабия през постсочиалистическия период. [w:] Бесарабските българи: история, култура и език (25-годишина нагрупата «Етнология на българите» в Центъра по етнология на Иститута културно наследство, АНМ и 20-годишнина на Научното дружество на българистите в Република Молдова), Кишинев«〈S.Ş.В.»), 2014, s. 249-262.

Голодомори в Україні: Одеська область 1921-1923, 1932-1933, 1946-1947. Дослідження, спогади, документи (Ред. I.I. Ніточко et alii), Державний архиів Одеської області, Одеса 2007.ss. 457

Голод в Молдове (1946-1947). Сборник документов (Сост. А.М. Царан et alii), Штиинца, Кишинев 1993, ss. 767.

Градешлиев И., Гагаузите, Издателска къшта „Людмил Бешков”, Добрич 1994, ss. 127.

Гургуров Д., Гагаузы - потомки тюрок-огузов или славяно-болгар?, Родно слово, Кишинев 1998, ss. 162.

Гургуров Д., „Язык поменяем, но веру сохраним!” или истина о происхождени гагаузов, Tipogr. Centrală, Chişinău 2008, ss. 128.

Державин Н.С., О наименовании и этнической принадлежности гагаузов [Из журнала Советская Этнография 1937 нр 1, с. 80-87], Tipogr. „Elena-V.I.”, Кишинэу 2005, ss. 24.

Етногенез и этническая история гагаузов. Материалы и исследования посвяшченные 150-летию B. Мошкова. Выпуск 1. [Составнение и редакция С.С. Курогло], Serv-Grafica Centrul de editură „Ekim” basım1, Кишинев - Етулия 2002, ss. 232.

Зайончковски В., К этногенезу гагаузов, „Folia Orientalia” 1974 nr 15, s. 77-86. 
Иванова Е., Гагаузите в Молдова, Международен Център за Изследоване на Малцинствата и Културните Взаимодействия (ИМИР), София 2004, ss. 13.

История и культура гагаузов (coord.S. Bulgar), Pontos, Комрат - Кишинэу 2006, ss. 740.

Каранастас-Радова О.К., Гагаузы в составе задунайских переселениев и их поселения в Буджаке (конец XVIII - первая четверть XIX вв); Tipogr. Komratskogo Gos. Un-t, Кишинев - Комрат 2001, ss. 131.

Квилонкова Е.Н., Гагаузский народныий календарь, Pontos, Chişinău 2002, ss. 182.

Квилинкова Е., Религиозность гагаузов и формы проявления религиозной идентичности (по этнографическим и архивным материалам ХИХ-первой половины ХХ в.). [w:] Этнографические исследования в Республике Молдова (История и современность), Кишинев 2006, s. 341-363.

Квилонкова Е.Н., Региональные особенности традиционной духовной культуры гагаузов, На правах рукописи, Кишинев 2008.

Квилонкова Е.Н., Заговоры, магия и обереги в народной медицине гагаузов, Elan INC, Кишинев 2010, ss. 389.

Квилонкова Е.Н., Гагаузский песенный фольклор - „граматика жизни”, Elan INC, Кишинев 2011, SS. 568.

Квилонкова Е.Н., Апокрифы в зеркале народной культуры гагаузов, Tipografia Cedntrală, КишиневБлагоевград 2012, ss. 599.

Квилонкова Е., Православие - стержень гагаузской этничности, Tipografia Centrală, Комрат-София 2013, ss. 866.

Кендигелян М., Гагаузская Республика. Борьба гагаузов за наџиональное самоопределене. 1989-1995. Воспоминания. Документы, Tipogr. Centrală, Комрат 2009, ss. 605.

Кубей и кубейци. Бит и култура на българите и гагаузите в с. Червеноармейское, Болградски район (А. Пригарин et alii), Одеска област, Маяк, Одеса 2002, ss. 86.

Манов Атанас, Потеклото на гагаузите и техните обичаи и нрави, Ч. 1-2, Печатница Светлина, Варна, 1938, ss. 182.

Курдогло Константин, Голод в Гагаузии (1946-1947 г2.), Tipografia Centrală, Комрат-Кишинев 2010, ss. 586.

Курдогло Константин, Репрессии и массовые депортаци жителей с. Баурчи Чадыр-Лунгского р-на Реапублики

Молдова в 1940-1951 г2, Tipogr. Centrală, Баурчи-Кишинэу 2009, ss. 607.

Матеева Ваня, Гагаузите - още един поглед, Академично Издателство „Марин Дринов”, София 2006, ss. 206.

Мошин Октавиан, Копущу Виктор, Протойерей Михаил Чакир: служние Богу и ближним. К 75-летию sо дня кончины протореиея Михаила Чакира, Cuvintul ABC, Кишинев 2013, Ss. 86.

Мошков Валентин, Гагаузы Бендерского уезда (Этнографические очерки и материаль), Tipogr. Centrală, Кишинев 2004, ss. 493.

Папцова Алла, Българите в Бесарабия не са готови да умират за идеите на украинските националисти - http://news.ibox.bg/interview/id_1793546393 [dostęp: 23.05.2015 r.]

Титоров Йов, Българите в Бесарабия, Печатница на Г.А. Ножаров, София 1903, ss. 332.

Чакир Михаил Протоиерей, История гагаузов Бессарабии. Страницы истории и литературы гагаузов XIX-нач. XX вв, Pontos, Кишинэу 2005, с. 80-108.

Шабашов Андрей, Гагаузы: система терминов родства и происхождение народа, Астропринт, Одесса 2002, ss. 740.

\section{Strony internetowe}

http://2001.ukrcensus.gov.ua/publications/ [dostęp: 25.07.2015 r.]. 